\title{
METHODOLOGY OF READINESS FORMATION FOR DIFFERENTIATION OF PROFESSIONAL TRAINING OF FUTURE TEACHERS OF MUSIC ART
}

\author{
Nataliia Ilinitska \\ Candidate of Pedagogical Sciences, Associate Professor, \\ Head of the Department of Instrumental-Performing Disciplines, \\ Khmelnytskyi Humanitarian-Pedagogical Academy, Ukraine \\ e-mail: ilinickaya.natalya1@gmail.com, orcid.org/0000-0001-8659-7781
}

\section{Summary}

The purpose of the article is to consider the effectiveness of the model of differentiation of professional training of future teachers of music art and methods of readiness formation for differentiation in professional training of music-students, during the formative experiment, which included a set of pedagogical activities, methods and techniques. The pedagogical experiment became a logical continuation of our theoretical research and was based on the following conceptual ideas: study of theoretical and methodical bases of differentiation of professional training of students; use of foreign tendencies differentiation of education in music pedagogy; introduction of methodological approaches as a basis for differentiation of music-pedagogical training; development and implementation of innovative technologies for working with students with different pre-university training; creation of organizational and pedagogical model of differentiation methodical system of professional training of musicians; making the atmosphere of creative cooperation between teacher and student.

The directions of work covered by the formative experiment included: methods of activating students' interests to music art and self-realization, self-improvement, self-differentiation in this area; the use of different types of activities in readiness formation for differentiation in the professional training of music-students; gradual formation of readiness for differentiation in professional training of educational process participants; realization of creative musical potential of each applicant for higher education.

Keywords: formative experiment, music-students, creative potential, self-differentiation.

DOI: https://doi.org/10.23856/4018

\section{Introduction}

Based on the analysis of scientific and literary sources, certain author's concept of differential education of future music art teachers, generalization of the results of the statement experiment and substantiation of the model of differentiation of professional training of music-students and methodology of readiness formation for differentiation in applicants' professional training for higher music education, a formative experiment was conducted.

The purpose of this work is to reveal the course of the formative experiment and the effectiveness of the methodology of readiness formation for differentiation of professional training of higher education applicants.

The scientific novelty lies in the implementation of the proposed methodology in teaching in the classroom (practical), in individual work and various creative projects of music-students.

Research analysis. Issues of differentiation are quite actively considered in secondary school. The development of theoretical provisions for differentiation and their implementation 
in the practice of higher education is slower. Such scientists as A. Gvozdeva and P. Gusak offer their concepts of differentiated education in higher educational institutions.

A. Gvozdeva believes that the basis for the differentiation of subjectivity is the differentiation of activities connected with the allocation of integral educational activities in relation to independent elements. Secondly, differentiation is determined by the individual organization of the subjects of educational activity (Gvozdeva A., 2009).

According to P. Husak, the technology of differentiated learning is considered as the organization of the educational process, which provides the formation of students' own style of activity on the basis of taking into account their individually-typological features. Differentiated learning involves a diverse grouping of students in order to develop appropriate optimal ways of learning (Husak P., 1999).

Verification of the effectiveness of the differentiation model of future music art teachers' professional training and methodology of readiness formation for differentiation in professional training of music-students, which contribute to the effectiveness of differentiation of higher education applicants of music speciality, was devoted to the formative experiment, which covered a set of pedagogical activities, methods and techniques. The pedagogical experiment became a logical continuation of our theoretical research, the main means of verifying the developed scientific provisions, assessing the effectiveness and practical significance of the reasonable models of differentiation of future music art teachers' professional training and methodology of readiness formation for differentiation in professional training of music-students.

\section{Conceptual ideas of work}

The organization of research work was based on the following conceptual ideas:

- study of theoretical and methodological bases of differentiation of professional training of students;

- the use of foreign trends in the differentiation of education in music pedagogy;

- introduction of methodological approaches as a basis for differentiation of music-pedagogical training;

- development and implementation of innovative technologies for working with students with different pre-university training;

- creation of organizational and pedagogical model of methodological system of differentiation of musicians' professional training;

- making the atmosphere of creative cooperation between teacher and student.

\section{Stages of experimental research}

The experimental part of the research allowed to highlight the stages of readiness formation for differentiation of future music art teachers' professional training: propaedeutic, approbation, organizational-stimulating and final.

Propaedeutic - was aimed at the theoretical elaboration of philosophical, psychological-pedagogical, music-pedagogical and musicological literature on the issue of differentiation in education. At this stage, a scientific-theoretical, methodological analysis of the problems of differentiated learning is done based on domestic and foreign scholars, who considered in their work the issue of differentiation of education in the process of future music art teachers' training. The scientific apparatus of the research was also developed, the main directions of the research and experimental work were substantiated. The working hypothesis is outlined. 
The approbation stage provided an opportunity to analyze the readiness for differentiation in art education. At this stage, the development of conceptual principles, components, indicators and levels of formation, also diagnostic tools of the study was provided, the model of differentiation of future music art teachers' studying was substantiated. The experimental basis of the research was determined and the state of readiness for differentiation of music-students' education was monitored (My xas `kova M., 2020: 366).

The organizational and stimulating stage is aimed at the opportunity to test the hypothesis and conceptual principles of readiness for differentiation of higher education applicants of music speciality. Referral of students to music-pedagogical activity, at the beginning with pedagogical support, and then without it, expansion of their abilities and skills of self-realization, self-improvement in the field of musical art. At this stage, the implementation of pedagogical principles and conditions was taken place, analysis and adjustment of intermediate results was performed.

The final stage of the study involves the final and comparative sections of the obtained results based on the original and intermediate data. Determining the features and dynamics of students' personal development whose study includes elements of differentiation and self-differentiation. Further directions' development of practical application of experimental work results based on the declared problem. Carrying out results, substantiation of conclusions and popularization of the concept of differentiation in musical specialties of higher educational institutions (Dzjuba E., 2010).

\section{Organizational forms of the educational process}

According to the stages of the developed methodology, the following organizational forms of the educational process were used on the basis of content differentiation. Such forms include:

- mono-purpose use of different types of educational activities to enhance the expected pedagogical result;

- gradual changes quantitative to qualitative in educational activities on the basis of differentiation and self-differentiation, which leads to a gradual complication of the content and ways of knowing; tic unity;

- comparative, which reveals the opposites of the studied objects in their (objects) didac-

- integrative, based on the use of one type of educational activity in which others are organically integrating, moreover the integration degree depends on the tasks set by the teacher and the student's personal interest;

- individual, which involves the organization of subject space in groups based on the individual characteristics of students, herewith this form allows you to transfer a student from one activity to another, contributing to the development of his potential opportunities (Gvozdeva A., 2009).

The formative experiment covered the following areas of work:

- methods of activating students' interests in the art of music and self-realization, self-improvement, self-differentiation in this field;

- the use of different activities in readiness formation for differentiation in music-students' professional training;

- gradual readiness formation for differentiation in the professional training of participants in the educational process;

- realization of creative musical potential of each higher education applicant. 


\section{The task of the molding experiment}

Based on the purpose of the research work, we had set the tasks of the formative experiment:

- to systematize and structure the process of differentiation of professional training of higher education applicants;

- to substantiate and describe the model of differentiation of future music art teachers professional training;

- to test the method of readiness formation for differentiation in music-students professional training.

\section{Methodological approaches}

The experiment is aimed at the holistic development of students, the implementation of the content of professional training. Professional training is focused on methodological approaches (acmeological, synergetic, competence, hermeneutic and phenomenological).

Acmeological approach to education is aimed at self-improvement of person in the educational environment through the differentiation and self-differentiation of students' knowledge, its development, movement from one peak to another, achieving acme at different levels of maturity, learning and creativity (Bocharova E., 2008: 7).

The synergetic approach is based on the dominance in educational activities of self-education, self-organization and consists in stimulating the subject with the aim of his self-disclosure and self-improvement, self-actualization in the process of cooperation with other people and with himself (Jakusheva S., 2012).

In the competency approach, professional competencies are in the center of the student's activity, ie, there is a restructuring into a student-centered in the educational process. The use of the competency approach involves not only the transfer of knowledge from teacher to student, but also the formation of professional skills and abilities of music-students to apply the acquired knowledge.

The purpose of the hermeneutic approach is the intensification of the process of self-development and self-realization of a student-musician, the activation of musical activity, which is not limited to the framework of classes. This requires the development of new ways of learning that differ in quality, ways of organizing educational activities (Mokienko O., 2011).

According to G. Zvenigorodskaya, the phenomenological approach, can be presented in pedagogy at the methodological level as an explanatory principle. The main function of the phenomenological approach is due to the ideas of self-development, preservation of human integrity in the educational process (Zvenigorodskaja G., 2002: 17).

The implementation of the methodology of readiness formation for differentiation in the professional training of music-students takes place in different types of activities: performing, methodical and music-theoretical. During training, with the help of pedagogical support, students have an internal self-differentiation, they determine what kind of musical activity is mostly demanded for them, where they can reveal their individuality. Gradually, pedagogical support decreases and the participants of the educational process realize themselves what kind of musical activity they will continue to develop (performing, conducting, vocal). Students who have more performing abilities, gradually in the process of learning determine for themselves the need for creativity during the performance of musical works.

Some students are more revealed in methodical activities (during practice at school). They are not only interested to observe, but also to participate personally in the educational 
process at the lessons conducted by school teachers and other trainees. They are interested in preparing for classes, thoughtfully approach their practical activities, are responsible for working as a teacher (have an interest in teaching, love for children, activity).

In music-theoretical activity students can reveal themselves as researchers, lecturers and musicologists. Research activities provide solutions to the following main tasks:

- formation of scientific worldview,

- providing assistance in achieving high professionalism;

- development of creative thinking and individual abilities;

- development of the initiative,

- the need for constant updating and improvement of their knowledge;

- expansion of theoretical horizons and scientific erudition;

- organization of creative teams within the walls of a higher educational institution, etc.

\section{Conclusions}

Thus, the study allowed to determine the components of the methodology of the molding experiment. The work was based on conceptual ideas, goals, objectives, stages of readiness formation for differentiation of future music art teachers professional training: propaedeutic, approbation, organizational-stimulating, final. Professional training of higher education applicants is focused on methodological approaches (acmeological, synergetic, competence, hermeneutic and phenomenological). Particular attention was paid to the implementation of the methodology of readiness formation for differentiation in the professional training of music-students, which took place in different activities: performing, methodical and musical-theoretical.

We see the use of methodology of readiness formation for differentiation in the professional training not only students of music-pedagogical institutions of higher education, but also students of art specialties as a prospect for further research.

\section{References}

Bocharova, E. P. (2008). Akmeologicheskij podhod k obrazovaniju. [Acmeological approach to education]. Pedagogika. Sociologija. № 4. P. 5-10. Vladivostok. [in Russian].

Gvozdeva, A. V. (2009). Integrativno-differencirovannyj podhod k razvitiju sub\#ektnosti studentov vuza v processe obuchenija francuzskomu jazyku: avtoref. dis. ... d-ra ped. nauk: 13.00.01., 13.00.02. Kursk. 2009. 52 s. [An integrative-differentiated approach to the development of the subjectivity of university students in the process of teaching French]. Kursk. [in Russian].

Gusak, P. M. (1999). Teoriya i texnologiya dy ferencijovanogo navchannya majbutnix uchy 'teliv pochatkovy x klasiv: avtoref. dy's. ... d-ra ped. nauk: 13.00.01. Ky yiv. 1999. 40 s. [Theory and technology of differentiated education of future primary school teachers]. Kiev. [in Ukrainian]. Dzjuba, E. A. (2010) Vnutrennjaja differenciacija kak faktor formirovanija individual'nyh obrazovatel'nyh traektorij studentov: avtoref. dis. ... kand. psih. nauk: 19.00.07. Rostov-naDonu. 2010. 22 s. [Internal differentiation as a factor in the formation of individual educational trajectories of students]. Rostov-on-Don. [in Russian].

Zvenigorodskaja, G. P. (2002). Teorija i praktika refleksivnogo obrazovanija na osnove fenomenologicheskogo podhoda: avtoref. dis. ... d-ra ped nauk: 13.00.01. Habarovsk, 2002. 39 s. [Theory and practice of reflective education based on the phenomenological approach]. Khabarovsk. [in Russian]. 
My'xas `kova, M. A. (2020) Sy ’stema formuvannya profesijnogo dosvidu muzy chno-pedagogichnoyi diyal nosti majbutnix uchy 'teliv muzy chnogo my stecztva: monografiya. [The system of formation of professional experience of music-pedagogical activity of future teachers of music art]. Khmelnytsky: FOP Melnyk A. A. [in Ukrainian].

Mokienko, O. P. (2011). Germenevticheskij podhod v obuchenii (na primere obuchenija literature). Vektor nauki Tol'jattinskogo gosudarstvennogo universiteta. Tol'jatti. Tol'jatti. 2011. Vyp 3(6). S. 204-206. [Hermeneutic approach to teaching (on the example of teaching literature)]. Tolyatti. Togliatti State University. [in Russian].

Jakusheva, S. D. (2012). Sinergeticheskij podhod v razvitii professional'nogo masterstva sovremennogo pedagoga. Aktual 'nye problemy pedagogiki i psihologii: materialy mezhdunar zaochnoj nauch.-prakt. konf., (g.Novosibirsk, Chast'II, 27 fevralja 2012g.). [A synergistic approach to the development of professional skills of a modern teacher]. Novosibirsk: Ed. "Siberian Association of Consultants». [in Russian]. 